\title{
Strategies for exchange of coconut germplasm in Brazil
}

\author{
Ana da Silva Lédo ${ }^{*}$ Leila Albuquerque Resende de Oliveira ${ }^{2}$ Caroline de Araújo Machado ${ }^{2}$ \\ Ana Veruska Cruz da Silva ${ }^{1}$ Semíramis Rabelo Ramalho Ramos ${ }^{1}$
}

${ }^{1}$ Embrapa Tabuleiros Costeiros, 49025-040, Aracaju, SE, Brasil. E-mail: ana.ledo@embrapa.br. "Corresponding author.

${ }^{2}$ Universidade Federal de Sergipe, São Cristovão, SE, Brasil.

\begin{abstract}
Seed size and its physiology are a barrier for the exchange of coconut genetics resources and the tissue culture techniques can assist the germplasm bank enrichment. The aim of this study was to evaluate the effect of transport and storage procedures of zygotic embryos to promote the exchange of coconut accessions. Mature zygotic embryo from Cameroon red dwarf (CRD), Malayan yellow dwarf (MYD) and Malayan red dwarf (MRD) were used. The following treatments were evaluated: T1-storage of endosperm disc in plastic bags at $10 \pm 2{ }^{\circ} \mathrm{C}$ for 5 days; T2 - 8 days; T3 - 12 days; T4 - embryo excised and inoculated in micro tube with Y3 culture medium with no sucrose for 2 days and T5 - five embryos inoculated in Y3 culture medium without sucrose in Petri dish for 2 days. T5 treatment resulted in low bacterial contamination.
\end{abstract}

Key words: Cocos nucifera, ex situ conservation, genetic resources, contamination.

Estratégias para intercâmbio de germoplasma de coco no Brasil

RESUMO: O tamanho da semente e sua fisiologia são barreiras para o intercambio de recursos genéticos de coqueiro e técnicas de cultura de tecidos podem auxiliar o enriquecimento de bancos de germoplasma. O objetivo deste estudo foi avaliar o efeito dos procedimentos de transporte e armazenamento de embriões zigóticos para o intercâmcio de acessos de coco. Foram utilizados embriões zigóticos maduros das variedades de coco anão vermelho dos Camarões (AVC), amarelo da Malásia (AAM) e vermelho da Malásia $(A V M)$. Os seguintes tratamentos foram avaliados: T1- de armazenamento de disco endosperma em sacos de plástico a $10 \pm 2{ }^{\circ} \mathrm{C}$ durante cinco dias; T2 - oito dias; T3 - doze dias; T4 - embrião inoculado em microtubo com meio Y3 sem sacarose por dois dias e; T5 cinco embriões inoculados em placa de Petri com meio de cultura Y3 sem sacarose por dois dias. O tratamento T5 resultou em baixa contaminação bacteriana baixa.

Palavras-chave: Cocos nucifera, conservação ex situ, recursos genéticos, contaminação.

With production of approximately 2 billion fruits per year in an area of 257,000 hectares, Brazil stands out as a major coconut producer, ranking fifth in the world (IBGE, 2015). Existence of genetic variability to support activities of genetic resources and improvement in developing new varieties is essential. To promote the International Coconut Genebank for Latin and Caribbean (Sergipe, Brazil) enrichment and exchange, it is necessary to implement the exchange of accessions. This activity, which consists of an orderly and systematic germplasm transfer, is held among countries through public and private institutions. However, even considering and following the protocols of each country, there is possibility of detection and transfer of pests and diseases, since some of the coconut diseases are geographically isolated (HARRISON \& ELLIOTT, 2008; CUETO et al., 2012). For example, the spread of lethal yellowing, caused by phytoplasm Candidatus or Cadang-Cadang, which is transmitted by the virus Coconut Cadang Cadang viroid-CCCVd, shows that caution is required when moving coconut plant material (HARRISON \& ELLIOTT, 2012; CUETO et al., 2012). Seed size and physiology is a barrier for the exchange of coconut genetics resources by seed and regarding the safe movement of germplasm, recent guidelines of the Bioversity International recommend the exchange through 
endosperm discs containing zygotic embryo or in vitro zygotic embryos (CUETO et al., 2012). However, studies have shown irregularity in the yield of coconut accessions introduced by endosperm discs and high percentages of contamination due to the time gap between collection, transport and inoculation of zygotic embryo (BANDUPRIYA et al., 2010; LÉDO et al., 2011).

The moving of coconut plant material through tissue culture is relatively safe; however, much emphasis has been given to the elimination of pathogens and maintenance of cultures free from contamination by bacteria, fungi and microarthropods (CASSELLS, 2012). Studies have reported how the type of explants, culture media and culture conditions can affect in vitro cultures in relation to contamination (PENCE et al., 2005; MSOGOYA et al., 2012; MUHAMMED et al., 2013). In this context, considering the need to enrich banks and the implementation of strategies for the safe movement, the aim of this study was to evaluate the effect of different transport, exchange and storage procedures on the in vitro contamination of zygotic coconut embryo accessions.

Approximately 1,200 zygotic embryos (400 per accessions) from adult plants of following coconut accessions were used: Cameroon red dwarf (CRD), Malayan yellow dwarf (MYD) and Malayan red dwarf (MRD). Endosperm cylinders containing zygotic embryos were removed from mature fruits (10-11 months old). Embryos were submitted to surface disinfection with $70 \%$ immersion for $1-2$ minutes in $2-2.5 \%$ commercial sodium hypochlorite for 30 minutes and triple washing in sterile water. For the evaluation of different exchange techniques in contamination and in vitro germination of zygotic embryos of coconut accessions, five procedures were applied: T1 - storage of endosperm disc in plastic bags at $10 \pm 2^{\circ} \mathrm{C}$ for 5 days; T2 - 8 days; T3 - 12 days; T4 - embryo excised and inoculated in micro tube with Y3 culture medium with no sucrose for 2 days and T5 - five embryos inoculated in Y3 culture medium without sucrose in Petri dish for 2 days. The storage temperature of endosperm discs treatments was defined based on recommendations of CUETO et al. (2012). After storage periods, endosperm discs were submitted to sterilization procedure previously described and the zygotic embryos (Figure 1a) inoculated into $250 \mathrm{ml}$ vials containing $30 \mathrm{ml}$ of $\mathrm{Y} 3$ culture medium (EEUWEENS, 1976) supplemented with $60 \mathrm{~g} \mathrm{~L}^{-1}$ sucrose, $1 \mathrm{~g} \mathrm{~L}^{-1}$ of activated charcoal, $5.8 \mathrm{~g} \mathrm{~L}^{-1}$ agar and $0.5 \mu \mathrm{M}$ of $\mathrm{GA} 3$ (germination medium). For embryo excised and inoculated in micro tube with Y3 culture medium with no sucrose for 2 days (Figure 1c) and five embryos inoculated in Y3 culture medium without sucrose in Petri dish for 2 days (Figure 1d) procedures, the endosperm discs were submitted to sterilization process as previously described and the embryos excised were inoculated in modified Y3 culture medium (without sucrose) with $5.8 \mathrm{~g} \mathrm{~L}^{-1}$ agar (transport medium) and after that transferred to germination medium (Figure 1b).

All cultures were kept in the dark until the emergence of leaf primordia. Then, they were transferred to an environment with a 16-h photoperiod, temperature of $25 \pm 2{ }^{\circ} \mathrm{C}$, average relative humidity of $70 \%$ and luminous intensity of $60 \mu \mathrm{mol} \mathrm{m} \mathrm{m}^{-2} \mathrm{~s}^{-1}$. After 30 days of in vitro culture, the percentage of fungal and bacterial contamination was determined. Data were transformed into $(\mathrm{X}+0.5) 1 / 2$, submitted to analysis of variance, and means of variables were compared by the Tukey test at 5\% probability, using the SISVAR statistical software.

There was no significant difference regarding the percentage of fungal contamination among coconut accessions and among exchange techniques at 30 days after inoculation, and values over $15 \%$ were not detected. There was no fungal contamination in MYD accession except in storage of endosperm disc in plastic bags at $10 \pm 2{ }^{\circ} \mathrm{C}$ for 5 days procedure. MRD and CRD accessions obtained 5\% contamination in $\mathrm{T} 2, \mathrm{~T} 3$ and $\mathrm{T} 5$ and $\mathrm{T} 1, \mathrm{~T} 2, \mathrm{~T} 4$ and $\mathrm{T} 5$, respectively (Table 1 ).

Low fungal infection rates $(1.38 \%)$ were also observed by LÉDO et al. (2011) nine days after inoculation of zygotic embryos of different accessions transported in endosperm discs stored in plastic bags at $17^{\circ} \mathrm{C}$ for two days. Significant differences among accessions and treatments and interaction of factors regarding bacterial contamination were observed. For CRD and MYD accessions, no effect of techniques on contamination was observed, i.e., the storage time of discs in plastic bags and inoculation of excised embryos in culture medium did not influence the appearance of bacterial contamination. As for MRD accession, the storage of five zygotic embryos in Petri dish containing Y3 culture medium for two days reached the lowest embryo contamination rate $(5 \%)$ compared to the other treatments. There was no bacterial contamination in MRD and MYD accessions submitted to storage of endosperm discs in plastic bags at $12 \pm 2^{\circ} \mathrm{C}$ for 12 days and in MYD when five zygotic embryos were inoculated in 

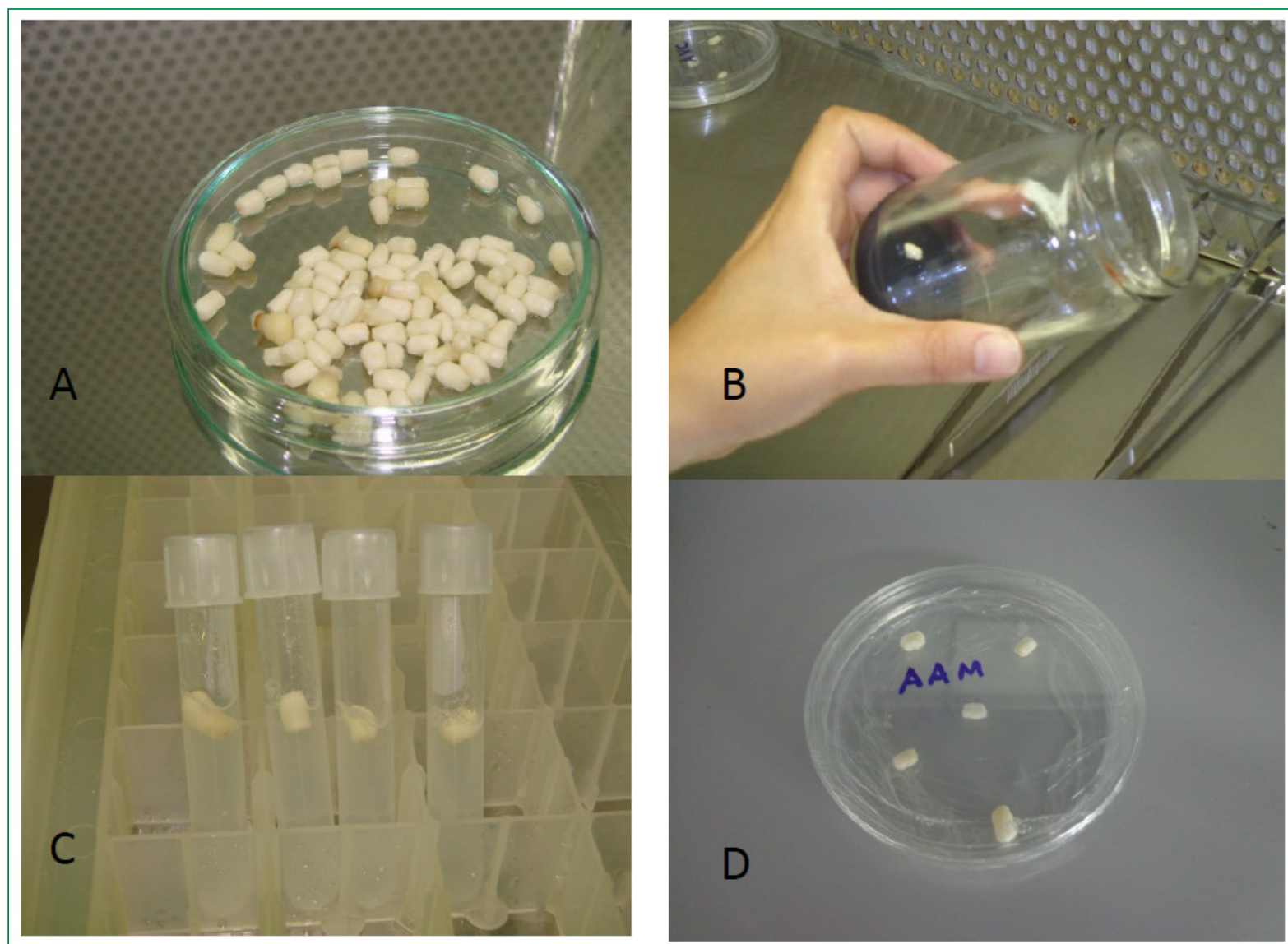

Figure 1 - Isolation of coconut zygotic embryos from Malayan yellow dwarf(MYD) accession: A - Excised zygotic embryos; B - Inoculation of zygotic embryo in Y3 culture medium; C - Embryos inoculated in $5 \mathrm{ml}$ micro tube; D - Embryos inoculated in Petri dishes. Photo: Ana Lédo, Caroline Machado.

Petri dish for two days. Evaluating different forms of transport of embryos and endosperm discs of giant coconut Gazelle accession and their effects on contamination, ASHBURNER \& THOMPSON (1993) concluded that the transport of endosperm discs in plastic bags reached $100 \%$ contamination. By contrast, there was no contamination in embryos excised and inoculated in sterile distilled water. High bacterial contamination rate $(33.98 \%)$ was also reported by LÉDO et al. (2011) in the exchange of endosperm discs of eleven dwarf coconut accessions and one giant coconut accession coming from the Germplasm Bank of Côte d'Ivoire (ICG-AIO) to the Germplasm Bank of Brazil (ICG-LAC). There were no significant differences among accessions submitted to storage of endosperm dises in plastic bags at $12 \pm 2^{\circ} \mathrm{C}$ for eight days and zygotic embryos inoculated in Petri dish for two days treatments. However, when the MRD accession was treated with storage of endosperm discs in plastic bags at $12 \pm 2^{\circ} \mathrm{C}$ for five and 12 days, and yours zygotic embryos were individually stored in $5 \mathrm{ml}$ microtube for two days it was possible observed the highest percentage of bacterial contamination when compared to MYD and CRD. Surface disinfection is generally effective in removing epiphytic contaminants, but much of the contamination resulting from in vitro collection originates from endophytic bacteria and fungi. The use of antimicrobial agents either in combination with surface disinfection or incorporated into the culture medium is required to eliminate these contaminants (PENCE \& SANDOVAL, 2002).

The results assist in the determination of strategies for the movement and introduction of coconut germplasm in Brazil and the transportation technique of zygotic embryos inoculated in Petri dish containing Y3 culture medium without sucrose can minimize the risk of introducing microorganisms. Further studies on the addition of antibiotics and fungicides should be conducted to minimize contamination of cultures. 
Table 1 - Percentage of fungal and bacterial contamination of mature zygotic embryos from Cameroon red dwarf (CRD), Malayan yellow dwarf (MYD) and Malayan red dwarf (MRD) accessions submitted to different exchange techniques at 30 days of in vitro culture.

\begin{tabular}{|c|c|c|c|}
\hline Procedures & $\mathrm{MRD}^{\mathrm{N} . S .}$ & $\mathrm{CRD}^{\mathrm{N.S} .}$ & MYD $^{\text {N.S. }}$ \\
\hline \multicolumn{4}{|c|}{------------Fungal contamination at 30 days (\%)------------ } \\
\hline $\mathrm{T} 1$ & 15 & 5 & 10 \\
\hline $\mathrm{T} 2$ & 5 & 5 & 0 \\
\hline $\mathrm{T} 3$ & 5 & 10 & 0 \\
\hline $\mathrm{T} 4$ & 10 & 5 & 0 \\
\hline $\mathrm{T} 5$ & 5 & 5 & 0 \\
\hline \multicolumn{4}{|c|}{----------Bacterial contamination at 30 days (\%)----------- } \\
\hline $\mathrm{T} 1$ & $25 \mathrm{BCa}$ & $20 \mathrm{Aab}$ & $5 \mathrm{Ab}$ \\
\hline $\mathrm{T} 2$ & $20 \mathrm{BCa}$ & $15 \mathrm{Aa}$ & $15 \mathrm{Aa}$ \\
\hline $\mathrm{T} 3$ & $30 \mathrm{Ba}$ & $0 \mathrm{Ab}$ & $0 \mathrm{Ab}$ \\
\hline $\mathrm{T} 4$ & $5 \mathrm{Ca}$ & $5 \mathrm{Aa}$ & $0 \mathrm{Aa}$ \\
\hline T5 & $55 \mathrm{Aa}$ & $15 \mathrm{Ab}$ & $5 \mathrm{Ab}$ \\
\hline
\end{tabular}

Means followed by the same lowercase in the row and uppercase in the column do not differ by the Tukey test at 5\% probability. T1 - Storage of endosperm discs in plastic bags at $12 \pm 2^{\circ} \mathrm{C}$ for five days; $\mathrm{T} 2$ - eight days; $\mathrm{T} 3$ - 12 days; T4 - five zygotic embryos inoculated in Petri dish for two days; T5 zygotic embryos individually stored in $5 \mathrm{ml}$ microtube for two days

\section{ACKNOWLEDGEMENTS}

The authors would like to thank Coordenação de Aperfeiçoamento de Pessoal de Nível Superior (CAPES) for granting a scholarship and Embrapa for the financial resources and infrastructure.

\section{REFERENCES}

BANDUPRIYA, H. D. D. et al. Cryopreservation of encapsulated plumules of coconut: effect of transport/store conditions. Asia Pacific Journal of Molecular Biology and Biotechnology, v.18, n.1, p. 135-137, 2010. Available from: < http://www.msmbb.org.my/ apjmbb/html181/181af.pdf>. Accessed: Jan. 25, 2016.

CASSELLS, A. C. Pathogen and biological contamination management in plant tissue culture: phytopathogens, vitro pathogens, and vitro pests. Methods in Molecular Biology, v.877, p.57-80, 2012. Available from:
$<$ http://www.ncbi.nlm.nih.gov/pubmed/22610620>. Accessed: Dec. 28, 2015. doi: 10.1007/978-1-61779-818-4 6

CUETO, C. A. et al. Technical guidelines for the safe movement and duplication of Coconut (Cocos nucifera L.) germplasm using embryo culture transfer protocols. Montpellier, France: COGENT, Bioversity International, 2012. 74p. Available from: <http://www. cogentnetwork.org/images/publications/tg-coconutembryotransfer. pdf>. Accessed: Jan. 30, 2016.

EEUWENS, C. J. Mineral requirements for growth and callus initiation os tissue explants excised from mature coconut palms (Cocos nucifera) and cultured in vitro. Physiologia Plantarum, v.36, p.23-28, 1976. Available from: < http://onlinelibrary.wiley.com/ doi/10.1111/j.1399-3054.1976.tb05022.x/abstract>. Accessed: Dec. 28, 2015. doi: 10.1111/j.1399-3054.1976.tb05022.x.

HARRISON, N. A.; ELLIOTT, M. L. Lethal yellowing of palms. The Plant Health Instructor. 2008. Available from: $<$ http://www.apsnet. org/edcenter/intropp/lessons/prokaryotes/Pages/LethalYellowing. aspx>. Accessed: Jan. 25, 2016. doi: 10.1094/PHI-I-2008-0714-01

HARRISON, N. A.; ELLIOTT, M. L. Lethal yellowing (LY) of palm. Gainesville: University of Florida, IFAS Extension, 2012. 7p. Available from: $<$ https://edis.ifas.ufl.edu/pp146>. Accessed: Jan. 25, 2016.

LÉDO, A. S. et al. Performance of coconut embryo culture accessions introduced at the International Coconut Genebank for Latin America and the Caribbean (ICG-LAC). Acta Horticulturae, n.918, p.177-182, 2011. Available from: <http://www.actahort.org/ members/showpdf?session=3177>. Accessed: Jan. 25, 2016.

MSOGOYA, T. et al. Identification and management of microbial contaminants of banana in vitro cultures. Journal of Applied Biosciences, v.55, p.3987-3994, 2012. Available from: <http:// www.m.elewa.org/JABS/2012/55/5.pdf>. Accessed: Jan. 20, 2016.

PENCE, V .C. et al. Controlling contamination during in vitro collecting. In: PENCE, V. C. et al. In vitro collecting techniques for germplasm conservation. Rome, Italy: IPGRI, 2002, p.30-40. (IPGRI technical Bulletin, 7). Available from: <https:/www.cabdirect.org/cabdirect/ FullTextPDF/2008/20083282488.pdf>. Accessed: Jan. 20, 2016.

PENCE, V. C. In vitro collecting (IVC). I. The effect of collecting method and antimicrobial agents on contamination in temperate and tropical collections. In Vitro Cellular \& Developmental Biology. Plant, v.41, n.3, p.324-332, 2005. Available from: <http://link. springer.com/article/10.1079\%2FIVP2004629\#page-1>. Accessed: Jan. 20, 2016. doi: 10.1079/IVP2004629.

MUHAMMED, N. R. et al. Zygotic embryo in vitro culture of Cocos nucifera L.(sv. East African Tall variety) in the coastal lowlands of Kenya. African Journal of Biotechnology, v.12, n.22, p.3435-3440, 2013. Available from: <http:/www.ajol.info/index.php/ajb/article/view/132027 /121626>. Accessed: Nov.10, 2015. doi: 10.5897/AJB2013.11940. 